\title{
Türkiye'de Biyogaz Üretimi İçin Başlıca Biyokütle Kaynakları
}

\author{
Halil ŞENOL ${ }^{*}$, Emre Aşkın ELİBOL ${ }^{2}$, Ünsal AÇIKEL ${ }^{3}$, Merve ŞENOL ${ }^{4}$ \\ $1^{*}$ Giresun Üniversitesi, Genetik ve Biyomühendislik Bölümü, Giresun \\ ${ }^{2}$ Giresun Üniversitesi, Makina Mühendisliği Bölümü, Giresun \\ ${ }^{3}$ Cumhuriyet Üniversitesi, Kimya Mühendisliği Bölümü, Sivas \\ ${ }^{4}$ Bulancak Anadolu Lisesi, Ingilizce ögrretmenliği Bölümü, Giresun
}

\begin{abstract}
Özet
Biyokütle, biyolojik olarak elde edilebilecek enerji potansiyeline sahip olan bir enerji kaynağıdır. Biyokütle her durumda oluşması ve tükenmez bir enerji kaynağı olması bakımından çok önemli bir değere sahiptir. Biyokütlenin enerji potansiyeli yenilenebilir enerji statüsünde yer aldığından, bu enerjinin tükenme riski yoktur. Dünya nüfusunun hızla artması enerji ihtiyacının da hızla artmasına neden olmuştur. Dünyamızın enerji kaynaklarının kullanımının \% 86' lık kısmını petrol, kömür ve doğal gaz oluşturmaktadır. Yenilenebilir enerji kullanım oranı yaklaşık \% 2,7' dir. $\mathrm{Bu} \%$ 86' lık kısım tükenmekte olan enerji rezervlerinden oluşmaktadır. Bu nedenle yenilenebilir enerji kaynakları iyice değerlendirilmeli ve bu enerji kaynaklarının kullanımı artırılmalıdır. Biyogaz yenilenebilir enerji kaynakları arasındaki büyük öneme sahip bir enerji kaynağıdır. Ülkemiz biyogaz üretimi için oldukça fazla biyokütle kaynaklarına sahiptir. Bu çalışmanın amacı ülkemizde biyogaz için mevcut olan özellikle organik atıklardan oluşan biyokütle kaynaklarının belirlenmesinden oluşmaktadır.
\end{abstract}

Anahtar kelimeler: Biyokütle, Yenilenebilir Enerji, Biyogaz, Organik Atıklar.

\section{Primary Biomass Sources for Biogas Production in Turkey}

\begin{abstract}
Biomass is an energy source that has a biologically obtainable energy potential. Biomass has a very important value in that it is formed in every situation and is an inexhaustible source of energy. Since biomass is involved in the energy potential renewable energy status, there is no risk of exhaustion of this energy. The rapid increase in world population has led to a rapid increase in energy demand. $86 \%$ of the world's energy resources are made up of oil, coal and natural gas. The rates of renewable energy usage is approximately $2.7 \%$. This $86 \%$ consists from exhaustible energy reserves. For this reason, renewable energy sources should be thoroughly evaluated and the use of these energy sources should be increased. Biogas is a major source of energy for renewable energy sources. Our country, for biogas production, has too many biomass sources. . The aim of this study is to identify biomass resources, especially organic wastes, which are available for biogas in our country.
\end{abstract}

Keywords: Biomass, Renewable Energy, Biogas, Organic wastes.

\section{Giriş}

Dünya nüfusunun ve sanayileşmenin hızla artması dünyada enerji ihtiyacını hızla artırmaktadır. Dünya enerji ihtiyacını yaklaşı \%24,2 doğalgaz, \% 29 kömür ve \% 32,8 petrolden karşılamaktadır. Geriye kalan kısım ise sadece nükleer enerji, hidro enerji ve yenilenebilir enerjidir. Dünyada doğalgaz, kömür ve petrol rezervleri tükenmekte olan enerji kaynaklarıdır. Ayrıca bu enerji kaynakları atmosferdeki karbondioksit $\left(\mathrm{CO}_{2}\right)$ emisyonunu artırdığından dolayı bu enerji kaynakları aslında doğa için oldukça zararlıdır [1].Yenilenebilir enerji kaynaklarından olan biyogaz enerjisinde ise bu durum çok farklıdır. Çünkü biyogaz enerjisi bileşenlerinden biri olan $\mathrm{CO}_{2}$ ise doğanın kullandığı karbondioksite eşittir ve bu

\footnotetext{
${ }^{*}$ Sorumlu yazar: halilsenol1990@hotmail.com

Geliş Tarihi: 20/05/2017 Kabul Tarihi: 02/10/2017

$\mathrm{Bu}$ çalışma CÜBAP tarafından M-686 nolu proje kapsamında desteklenmiştir.
} 
nedenle atmosfere zararlı değildir ve kirlilik etkisi yaratmaz [2]. Biyokütleden elde edilen biyogaz ise, içeriğindeki metan $\left(\mathrm{CH}_{4}\right)$ gazı sayesinde tükenmekte olan doğal gaz enerjisinin yerine geçebilecek en büyük potansiyeldir [3].

Biyokütle kullanılarak farklı ihtiyaç alanlarına yönelik katı, sıvı ve gaz formlarında değişik enerji ürünleri elde edilebilir. Biyokütle enerjisinin kolay depolanabilir olması da diğer yenilenebilir enerji kaynaklarına göre avantaj sağlar [4]. Biyokütle genel olarak 6 farklı metodla kullanılabilmektedir. Bunlar doğrudan yakma, gazlaştırma, piroliz, aneorobik çütrütme ve co-firing metoduyla biyoyakıt ve kömür yakıtları beraber kullanılarak enerji üretiminde kullanılabilmektedir [5].

Biyokütle dünya toplam birincil enerji ihtiyacının yaklaşı \%10'unu oluşturan, 1sıtma ve ulaşımdaki kullanımının yanı sıra, elektrik üretimi amacıyla da kullanılır. Elektrik üretiminde biyokütle enerjisi, yenilenebilir enerji kaynakları arasında rüzgardan sonra ikinci sırada gelmektedir, güneş enerjisine dayalı üretim ise üçüncü sırada gelmektedir [5].

Ülkemiz biyokütle kaynakları ve organik atık kaynakları açısında oldukça zengin bir potansiyele sahiptir. Fakat ülkemiz ürettiği enerjinin yaklaşık üç katını tüketen bir ülkedir. Bu nedenle enerji ihtiyacı açısından dışarıya bağımlılığımız \%70 in üzerindedir. Ayrıca Türkiye'nin biyogaz potansiyeli mevcut doğal gaz kullanımının \% 88'ine eşdeğerdir [6].

Biyogaz birçok biyokütlelerden elde edilebilen bir enerji kaynağıdır. Böylece biyogaz çeşitli organik maddelerden veya organik atıklardan üretilebilen bir enerji kaynağı olarak karşımıza çıkmaktadır [7]. Biyogaz üretimi sonucunda oluşan gaz saf bir gaz değildir. Bu gazın içeriğinde yaklaşık olarak \% 55$75 \mathrm{CH}_{4}$ gazı, \% 25-45 $\mathrm{CO}_{2}$ gazı, \%1-10 hidrojen gazı $\left(\mathrm{H}_{2}\right)$, \% $0-0,3$ azot $\left(\mathrm{N}_{2}\right)$ gazı ve \% 0-3 hidrojen sülfür gazı $\left(\mathrm{H}_{2} \mathrm{~S}\right)$ içermektedir [8].

Ülkemizdeki organik atıklar genel toplam atıkların \% 65'i dir. Bu nedenle ülkemiz çok büyük bir organik atık kapasitesine sahiptir. Bu atıklar kontrolsüz bir şekilde çevreye atılmakta ve çürümeye terk edilmektedir. Bu nedenle çevre kirliliği oluşturmaktadır. Böylece bu atıkların değerlendirilmesi hem çevre kirliliği açısından hem de enerji ihtiyacı açısından önem kazanmaktadır [4].

Biyokütlelerden anaerobik sindirimle biyogaz üretiminin birçok avantajı vardır. Bu avantajlara ek olarak anaerobik sindirim doğa ve bitkiler için ihtiyaç olan N ve F un geri kazanılmasını sağlar $[9,10]$.

Bitkisel ve hayvansal organik maddeler, çoğunlukla ya çevreye atılarak doğaya zararlı bir hale gelmektedir ya da doğrudan yakılmaktadır. Bir başka alternatif olarak ise tarım için topraklara doğrudan gübre olarak kullanılabilmektedir [11]. Fakat bu tür gübreler doğrudan toprağa kullanıldığ 1 için zararlıdır. Çünkü bu gübrelerin oluşum aşamasında hayvanların veteriner tarafından kullanılan aşılar, yedikleri zararlı yem karışımları vb. gibi maddelerden dolayı yapısında patojen bakterilerin oluşumu gerçekleşmektedir. Bu nedenle bu patojen bakteriler tarımda ki toprak verimini aksine daha da verimsiz hale getirebilme potansiyeline sahiptir [12]. Fakat biyogaz sonucu oluşan yan ürünler organik bir gübre olarak kullanabilme potansiyeline sahiptir. Bu nedenle özellikle hayvan gübresinden oluşan organik atıklar anaerobik sindirim sonucu oluşan gübre özellikle toprak verimini \%10 artırmaktadır. Böylece organik gübre için biyogaz üretimi yapmak hem biyogaz üretiminden enerji elde etmek için faydalı hem de organik gübre elde edilmesi açısından avantajlıdır [13].

\subsection{Biyogaz Üretiminin Avantajları}

- Temiz enerji kaynağıdır.

- Çevre dostu ve ucuz bir enerji ve gübre kaynağı olarak nitelendirilebilir.

- Atıkların değerlendirilmesini sağlar.

- Biyogaz üretimi sayesinde oluşan organik gübrede hayvan gübresinde bulunan yabancı ot tohumları çimlenme özelliğini kaybeder.

- Biyogaz üretimi sonucunda hayvan gübresindeki istenmeyen koku tamamen yok olmaktadır.

- Biyogaz üretimi sonucunda hem atıklar yok olmaz hem de çok değerli bir organik gübreye 
dönüşür.

- Hayvansal kaynaklarda bulunan yabancı bileşenler yer altı sularını tehdit etmektedirler. Bu tehditler biyogaz üretimi sayesinde ortadan kalkmaktadır. Çünkü organik bileşenlerden üretilen biyogaz çok temiz bir yan ürüne sahiptir.

- Biyogaz çok yönlü bir enerji kaynağıdır ve hem 1sıtma hem de elektrik üretimi amaciyla kullanılabilir.

- İçeriğinde \% $95 \mathrm{CH}_{4}$ içeren biyogaz doğal gaz saatlerinde ufak bir değişiklik yaparak doğal gazın yerine kullanılabilmektedir.

- Biyogaz, sıvılaştırılmış petrol gazı ile çalışan sobaların meme çaplarında basınç ayarlaması yapılarak kolaylıkla kullanılabilir [14].

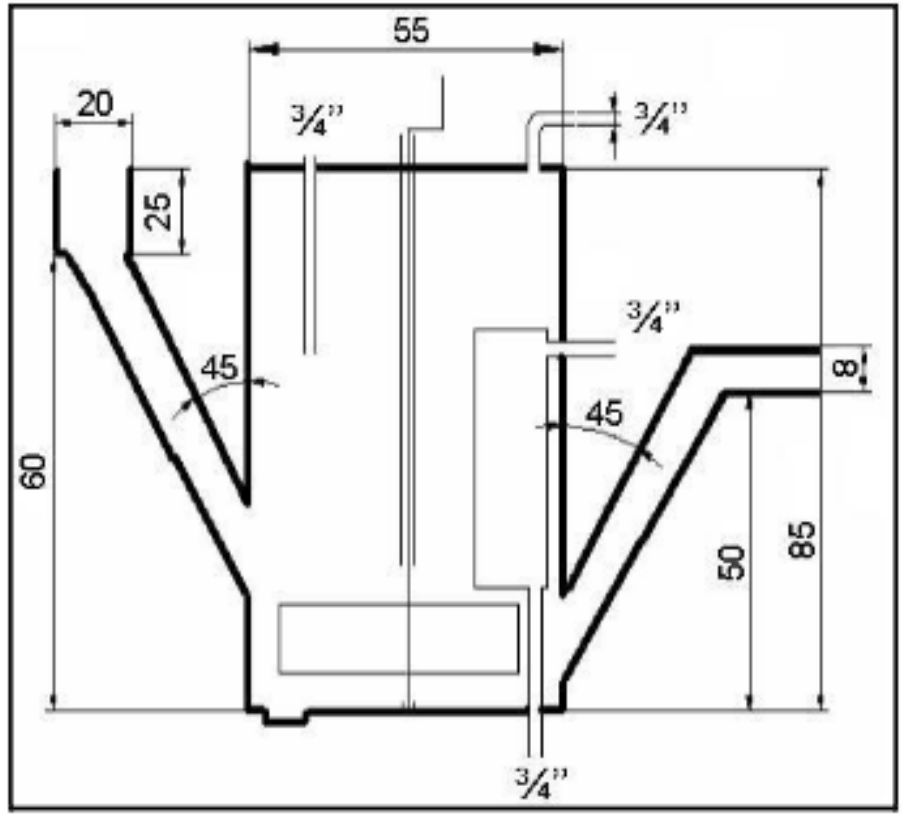

Şekil 1. Biyogaz reaktörü örneği.

Yukarıdaki Şekil.1 de standart biyogaz üretim sisteminin reaktörü verilmiştir. Şekil 1 de görüldügü gibi biyogaz üretim reaktörü oluşturulurken çok pahalı olan malzemeler kullanılmasına gerek yoktur ve reaktörün imalatı için çok özel işçilik maliyeti geliştirilmemiştir [15].

\subsection{Biyogaz Üretimini Etkileyen Faktörler}

\subsection{1. pH}

Biyogaz üretimi için en uygun $\mathrm{pH}$ değeri 6,8 ila 7 arasında olmalıdır. Biyogaz oluşumu aşamasında yani anaerobik fermantasyon işlemi sırasında $\mathrm{pH}$ değeri 7 ile 7,5 arasında değişir. $\mathrm{pH}$ değerinin 6,7 nin altına düşmesi durumunda ise metanojen bakteriler üzerinde toksik etki yapar. Anaerobik fermantasyon sırasında asit oluşturucu bakterilerin artması $\mathrm{pH}$ in düşmesine sebep olmaktadır. Bu tür proseslerde reaktöre organik yükleme kesilerek asit oluşumunun düşmesi sağlanmaktadır. $\mathrm{pH}$ in kararlı hale gelebilmesi için sönmüş kireç olarak adlandırılan kalsiyum hidroksit $\mathrm{Ca}(\mathrm{OH})_{2}$ kimyasalı da kullanılabilir [16].

\subsubsection{C/N Oranı}

Metonojen ve anaerobik bakteriler karbon (C) atomunu enerji elde etmek için ve azot $(\mathrm{N})$ atomunu da bakterilerin büyümesi ve üremesi için gerekli bileşenlerdir. $\mathrm{C} / \mathrm{N}$ oran1 23 den fazla ve 10 dan düşük olamaz. Eğer 10 dan düşük olursa reaktörde amonyak oluşumu olur ve bu oluşum biyogaz üretimini olumsuz etkiler. Eğer 23 ten fazla olursa uçucu yağ asitleri oluşur ve inhibitör etki yaparak biyogaz üretimini yavaşlatır. [16]. 


\subsubsection{Organik Yükleme Hızı}

Organik yükleme hızı $\mathrm{m}^{3}$ basına biyoreaktöre beslenen organik madde miktarıdır. Organik yüklenme hızı hesaplanarak optimum değerde sabitlenmelidir ki aksi halde $\mathrm{pH}$ yükselerek biyogaz üretimi durabilmektedir. Mezofilik şartlarda organik yüklenme hızı sığır gübresi için 2,5-3,5 $\mathrm{kg} \mathrm{UM} / \mathrm{m}^{3}$.gün (uçucu madde/metreküp. gün) olarak, besin maddeli organik beslemeler için 5,0-7,0 kg UM/m ${ }^{3}$.gün, domuz gübresi için ise $3,0-3,5 \mathrm{~kg} \mathrm{UM} / \mathrm{m}^{3}$.gün olmalıdır [16].

\subsubsection{Toksisite}

Biyoreaktöre beslenen tavuk ve büyükbaş hayvan gübrelerin bazılarında antibiyotikler bulunmaktadır. $\mathrm{Bu}$ antibiyotikler biyogaz üretimini sağlayan biyoreaktör için olumsuz etki yapmaktadır. Aynı şekilde substrat olarak kullanılan organik maddenin içerisinde bulunan ağır metaller, mineraller, deterjanlar vb. yabancı maddeler biyogaz oluşumunu olumsuz etkilemektedir [16].

\subsubsection{Sicaklık}

Tablo 1.Metanojen bakteri türleri ve çalışma sıcaklıkları

\begin{tabular}{cc}
\hline Bakteri türleri & Optimum aktivite $\left({ }^{\circ} \mathrm{C}\right)$ \\
\hline Sakrofilik & $5-25$ \\
Mezofilik & $25-38$ \\
Termofilik & $50-60$ \\
\hline
\end{tabular}

Yukaridaki Tablo 1 de biyogaz üretimini gerçekleştiren bakteri türleri ve bu bakterilerin çalıştı̆̆ ortalama sıcaklık aralıkları verilmiştir [12]. Biyogaz üretimi için sıcaklık çok önemli bir değerdir. Özellikle bu sıcaklığın $10^{\circ} \mathrm{C}^{\prime}$ nin altına düşmesi durumunda biyogaz üretimi durmaktadır[17].

\subsubsection{Katı Madde Oranı}

Biyoreaktörde ki substratın optimum biyogaz oluşumu için tesis içi gübre-su karışımının katı madde oranının \%7-9 olması gerekmektedir. Katı madde oranları; sı ğır gübresinde \% 15-20 civarında, tavuk gübresinde $\% 30$ ve koyun gübresinde de $\% 40$ civarındadır [18]. Uygun katı madde oranı belirli hesaplamalar doğrultusunda suyla karıştırılarak hesaplanabilir.

\subsubsection{Karıştırma Hızı}

Biyogaz üretiminde ayrıca karıştırma hızı ve substratın tanecik boyutu da etki etmektedir. Tanecik boyutuyla biyogaz üretim hızı ters orantılıdır. Karıștırma hızı ile biyogaz üretimi ile doğru orantılıdır [19]. Karıştırma aynı zamanda alt kısımlarda oluşan biyogazın yukarı çıkmasını ve daha iyi bir bakteri aktivitesi sağlar.

\section{Biyogaz Üretimi İçin Çeşitli Biyokütle Kaynakları}

Biyogaz üretimi için çeşitli biyokütle kaynakları olarak ülkemizde bulunan başlıca organik atıklardan bahsedilecektir. $\mathrm{Bu}$ organik atıkların bertaraf edilmesi çevre kirliliği açısından son derece önem kazanmaktadir.

\subsection{Hayvan Gübreleri}

Büyükbaş hayvan gübresi, biyogaz üretimi proseslerinde genel olarak sığır, manda, at ve domuz gübresi olarak nitelendirilir. Küçükbaş hayvanlar ise genellikle koyun ve keçi olarak bilinmektedir. Bu büyükbaş ve küçükbaş hayvanların gübrelerine ahır gübresi de denilmektedir. Hayvan gübreleri biyogaz üretimi için önemli bir potansiyele sahiptir. Hayvanların merada veya ahırda beslenmeleri günlük gübre üretimini etkilemektedir. Ortalama olarak 1 ton sığır gübresinden yaklaşık $33 \mathrm{~m}^{3}, 1$ ton koyun gübresinden $58 \mathrm{~m}^{3}$ ve 1 ton kümes hayvanları gübresinden $78 \mathrm{~m}^{3}$ biyogaz üretilebilmektedir [20]. 
Hayvan gübrelerinden sığır gübresinin biyogaz verimi yaklaşık olarak 90-310 litre/kg olarak bilinmektedir ve sığır gübresinden oluşan metan gazı oranı hacimsel olarak \% 65 dir [21]. Sığır gübresi sonucu üretilen biyogaz sonucunda oluşan yan ürün tarımda kullanılarak toprağa verilirse toprak verimi artmakta ve toprağın organik madde miktarını artırmaktadır. Ahır gübreleri hem bitki için besin maddesi kaynağıdır hem de toprağın fiziksel, kimyasal ve biyolojik özelliklerini düzenleyen bir toprak düzenleyicidir. Fermente olmuş ahır gübreleri toprağın işlenmesini kolaylaştırır. Toprağa bitki gelişimi için uygun hale getirir. Kumlu yapıdaki topraklarda ise toprakların birbirine yapışmasını sağlar. Ahır gübrelerinin en önemli özelliklerinden biride çok zengin bir mikroorganizma içeriğine sahip olmasıdır [22]. Biyogaz üretimi için sığır gübresinin $\mathrm{C} / \mathrm{N}$ oranı 21 olup biyogaz üretimi için oldukça ideal bir gübredir. Ülkemiz 2016 yılında 14 milyon büyükbaş hayvana sahiptir ve yıllık gübre üretimi ise yaklaşık 50 milyon ton (megaton) yaş gübre mevcut olmaktadır. $\mathrm{Bu}$ da ülkemizin biyogaz potansiyeli bakımından çok zengin olduğunu kanıtlamaktadır.

\subsection{Kanatlı Gübresi}

Kanatlı üretimin başladığı ilk zamanlarda sorun olarak görülmemiş ve diğer hayvan gübreleri gibi geleneksel yöntemlerle tam olarak kompostlama yapılmadan tarım topraklarına verilmiştir. Fakat bu işlem sonucunda fermente olmamış yaş gübre toprağa verildikten sonra bu gübrenin patojen mikroorganizmaları barındırdığı ortaya çıkmıştır. Yeterli uygun değerlendirme yöntemlerinin olmaması ve kurutma tekniklerinin maliyeti artırmasıyla, yerleşim birimleri etrafinda kurulmuş büyük kapasitedeki tavukçuluk işletmelerinin genelde \% 50 civarında sulandırarak depoladıkları tavuk gübreleri çevre açısından koku, sinek kaynăğ, atmosfer ve su kirliliğine neden olmaktadır [23].

Ekonomik yapısı gereği temelde bir tarım ve hayvancılık ülkesi olan yurdumuzda çok miktarda büyükbaş, küçükbaş ve kanatlı hayvan yetiştirilmektedir. 1999 yılı itibarı ile ülkemizde 167,6 milyon et tavuğu ve 70,8 milyon yumurta tavuğu olmak üzere toplam 238,4 milyon kanatlı hayvan beslendiği göz önünde bulundurulacak olursa hayvancılıkta kanatlı hayvanların ayrı bir yer aldığı anlaşılır. 2016 yılında ise Türkiye İstatistik Kurumu (TÜIK) verilerine göre bu sayı 320,4 milyona ulaşmıştır [24].

Çevre kirliliği konuları arasında kanatlı hayvanların yaş gübrelerinin büyük payı vardır. Özellikle tavuk gübresi hoş olmayan bir koku ile çevreyi kirletmektedir. Dünyada her ülke kendi ekonomisine ve gereksinimine uygun yöntem arayışı içerisine girmiştir. Gelişmiş ülkelerde de tavuk gübresi birçok şekilde değerlendirilmektedir. Bazı ülkelerde biyogaz tesisleri kurularak, tavuk gübresinden elde edilen biyogaz, enerjiye dönüştürülerek değerlendirilmektedir. Bu şekilde atık olarak nitelendirilen tavuk gübresinden hem biyogaz elde edilerek enerji sağlanması hem de kompost elde edilmesi sağlanmaktadır. Dünya da yaygın olarak tavuk gübrelerinin \%95'i kompost gübre, büyükbaş hayvan yem üretimi ve yakıt olarak kullanılmaktadır [23].

Tavuk gübresinin $\mathrm{C} / \mathrm{N}$ oranı 14' tür. [25]. Tavuk gübresi biyogaz üretimi için tek substrat olarak kullanılabilmektedir. Çünkü biyoreaktörde gerekli olan ideal $\mathrm{C} / \mathrm{N}$ oranı 10-21 arasındaki değeri karşılamaktadır.

1 ton yaş tavuk gübresinden ortalama $78 \mathrm{~m}^{3}$ biyogaz üretilebilmektedir [26]. Tavuk gübresinden üretilen biyogazın içeriğindeki metan oranı ortalama \% 60' tır [27] .1 kanatlı günde ortalama 0,08-0,1 kg kadar yaş gübre üretmektedir [20]. Böylece ortalama bu rakamı $0.09 \mathrm{~kg}$ olarak kabul edersek ve ülkemizde toplam 320 milyon kanatlı gübre varsa 288.000 ton/gün yaş kanatlı hayvan gübresi üretilmiş olur. Buda çok büyük bir biyogaz üretim potansiyeline eşittir.

\subsection{Kentsel Katı Atıklar}

Biyogaz üretimini kentsel katı atıklardan sağlamak için iki tane genel yöntem bulunmaktadır. Birinci yöntem bu kentsel katı atıkların organik kısmının diğer kısımlardan ayrılması ve bu organik kısımlardan oksijensiz fermantasyon biyogaz üretilmesidir. $\mathrm{Bu}$ yönteme biyometanizasyon denilmektedir. $\mathrm{Bu}$ yöntem ile gaz üretimi genellikle daha verimlidir. Çünkü üretilen gazın kaynağı sadece organik atılardır. İkinci yöntem ise bu kentsel katı atıkların atık depolarında biriktirilmesiyle doğrudan oksijensiz fermantasyon ile biyogaz üretimidir. Bu şekilde üretilen gaza ise LFG gaz (Land-fill gas) veya deponi gaz denilmektedir [28]. 
Anaerobik fermantasyon işlemi biyoreaktörlerde gerçekleşmektedir. Biyogazın üretimi yapıldığı biyogaz tesisleri bazı özelliklerine göre kendi içlerinde farklı gruplara ayrılmaktadırlar. Bu özellikler farklı katı madde yüzdesi, kademe sayısı ve prosesin sıcaklığıdır [29]. Standart bir evsel atığın depolama sahasının ömrü boyuna ürettiği depo gazı oranı ortalama $200 \mathrm{~m}^{3} /$ ton' dur.

Atık hizmeti veren belediyeler bir hesaplaması yapılabilir. Türkiye'de 3225 adet belediye bulunmaktadır ve bunlar arasinda yer alan sadece 3129 belediye atık hizmeti vermektedir. Bu hizmeti alan toplam ortalama nüfus $57.800 .347^{\prime}$ 'dir. Kentsel atık miktarlarının ortalaması alındığında günlük olarak kişi başına düşen miktar $1,15 \mathrm{~kg} / \mathrm{kişi.gün'} \mathrm{dür} \mathrm{[30].} \mathrm{Bu} \mathrm{değere} \mathrm{göre,} \mathrm{bir} \mathrm{kişi} \mathrm{yıllık} \mathrm{olarak} \mathrm{ortalama} \mathrm{0,42}$ ton/kişi.yıl atık oluşturur [31]. Atık hizmeti alan toplam nüfusun ortalama yıllık atık miktarı 24.276.145 ton/yıl dır. Çöp gazının 1sı değeri $18-27 \mathrm{~kJ} / \mathrm{Nm}^{3}$ arasında değişmektedir. $5.10-3 \mathrm{kwh} / \mathrm{Nm}^{3}$ 1sı değeri için çöp gazının ortalama enerji potansiyeli, yaklaşı olarak 4,85 milyon $\mathrm{kWh}$ olarak bulunur [32]. $\mathrm{Bu}$ değerler dikkate alınacak olursa ülkemiz devasa bir kentsel bir organik katı atıklara sahiptir. Bu da kentsel katı atıklarının oldukça iyi bir biyogaz üretim potansiyeline sahip olduğunu açıklar.

\subsection{Tarımsal Atıklar}

Ülkemizde ortalama olarak tarım sektöründen ( arpa, buğday, tütün, çeltik, pamuk vb. zirai atıklar) yıllık olarak 65 Mton atık üretilmektedir [33]. Bu atıklar tarımsal çevrede çok büyük bir kirliliğe sebep olmaktadır. Örneğin buğday samanı atıkları bertaraf edilmesi için yakılarak atmosfere $\mathrm{CO}_{2}$ salgılanmasını sağlamaktadır. Bu durumda hava kirliliğine yol açmaktadır [34].

Tarımda birim alan başına elde edilebilecek verimin artırılması belirli bir seviyeye kadar mümkün olabilmektedir. Ancak tarımsal ürünlerden daha fazla gelir elde etmenin ve yerel kalkınmayı desteklemenin ve köyden kente göçlerin azaltmayı desteklemenin önemli yollarından biride tarımsal organik biyokütleleri değerlendirmektedir. Bu değerlendirmelere alternatif bir kaynak aneorobik fermentasyonla biyogaz üretimidir [35].

$1 \mathrm{~kg}$ buğday ya da arpa samanından ortalama 250 litre biyogaz üretilebilmektedir ve bu biyogazın içeriğindeki $\mathrm{CH}_{4}$ oranı \%60' dır. Mısır sapları ve atıklarından ortalama yaklaşı 420 litre biyogaz elde edilmektedir ve bu biyogazın $\mathrm{CH}_{4}$ içeriği ise ortalama \% 59 dur. $1 \mathrm{~kg}$ yer fistığı kabuklarından ortalama yaklaşık 365 litre biyogaz üretilebilmektedir. [36].

1 ton mısır silajından yaklaşık $185 \mathrm{~m}^{3}$ biyogaz üretilmektedir. Mısır silajı, mısır bitkisinin kıyma şeklinde parçacıklar haline gelmesiyle oluşturulur ve bu parçacıklar sayesinde mısır bitkisinin yüzey alanı artırılır. Hem yüzey alanının artmasından dolayı hem de metrekare başına çok yüksek verim vermesinden dolayı biyogaz üretiminde sıklıkla kullanılmaktadır [37].

\subsection{Yer Fistığı Kabuğu}

Kabukları \% 5 azot, \% 3 potas ve silis içerdiğinden hayvan yemi veya suni tahta yapımında da kullanılabilir. Kabuklar yakacak olarak kullanıldığı gibi, teneke ve bakır kapların parlatılmasının yanında biyogaz üretiminde de kullanılması alternatif bir kaynaktır. [38]. Ülkemiz yer fistığı son yıllarda yıllık olarak yaklaşık 123.600 ton kadar üretilmektedir. Yer fistığı üreticiliği açısından ülkemiz dünyada önemli bir yere sahiptir. Ülkemiz, Dünyada fıstık üreten sayılı ülkeler arasındadır [39].

Yer fıstığı bertaraf yöntemlerinin en kazançlı ve uygun yöntemi anaerobik fermantasyondur. Yukarıdaki paragrafta belirtildiği gibi ülkemiz yer fistığı ve kabuğu açısından oldukça iyi bir potansiyele sahiptir. $\mathrm{Bu}$ nedenle yer fistığ 1 kabuğu büyük bir biyogaz üretim potansiyeline sahiptir. 1 kg yer fistığ fistık kabuğundan ortalama 365 litre biyogaz üretilebilmektedir [40].

\subsection{Zeytin Karasuyu}

2007 yılı verilerine göre; Marmara Bölgesi’nde üretilen yıllık zeytin miktarı yaklaşık 1.200.000 ton’ dur. Bunun 365.000 tonu sofrada yenilebilir olarak, geriye kalan 835.000 tonu ise yağlık zeytin olarak üretilmektedir. Sonuç olarak, takriben 130.000 ton zeytinyağı üretilmektedir [41]. Buna göre, zeytinyağ1 sıkma teknolojisine bağlı olarak oluşan sıvı atık kısmı değişmekle birlikte genel olarak açığa çıkan atık 
su miktarı ortalama $0,5-1,5 \mathrm{~m}^{3} /$ ton zeytin olmaktadır [42]. Bu değerler göz önünde bulundurulduğunda ortalama 450.000 ila 1.200 .000 zeytin atığı işlenmediği takdirde çevreyi kirletmektedir [43].

Zeytin kara suyu derişimi, işletim koşullarına ve üretim sürecine bağlı olarak büyük değişimler gösterir. Geleneksel sıkma yönteminde, 1 ton zeytin başına ortalama $0,6 \mathrm{~m}^{3}$ atıksu çıkmaktadır (KOİ $=90-130$ $\mathrm{g} / \mathrm{L}$ ). Bu yöntemin iki fazlı sürekli sisteminde zeytin atıksu oranı $0,1 \mathrm{~m}^{3}$ atıksu/ton zeytin dir. Bunun KOİ değeri de 10 - $15 \mathrm{~g} / \mathrm{L}$ olarak bilinmektedir. Aynı şekilde bu yöntemin üç fazlı sürekli sistemde ise zeytin atıksu oranı 1 ton zeytin başına ortalama $1,0-1,2 \mathrm{~m}^{3}$ atıksu/ ton zeytin dir. Bunun KOİ değeri ise 40-220 g/L olarak değişmektedir. Zeytinde açığa çıkan atıksu miktarının bir başka altarnatifi ise zeytinyağ 1 üretimidir. Bu üretimden açığa çıkan atıksu miktarı ise ortalama $0,5-1,5 \mathrm{~m}^{3} /$ ton miktarları arasında değişiklik göstermektedir [44].

Ülkemizde bir yılda atık olarak üretilen zeytin karasuyu, yaklaşık olarak ülkemizde 20 milyon insanın oluşturduğu atık suya karşılık gelmektedir. Zeytin karasuyunu nehirlere göllere atmak yerine doğrudan toprağa vermek te toprağın yapısına zarar vermektedir. Ayrıca zeytin karasuyunun yapısında bulunan fenolik bileşen içeriği yüksek olduğundan dolayı bu atığın toprağa atılması sırasında atıklar doğrudan yüzey sularıyla karışmakta ve kirlilik oluşturmaktadır. Zeytin karasuyunda bulunan yüksek miktardaki şeker ise mikrobiyal solunumu canlandırmaktadır ve suda çözünen oksijen miktarını azaltmaktadır. Bununla beraber zeytin karasuları buharlaşma havuzlarında kötü kokuya sebep olmakta ve kaynak sularını da kirletmektedir. Buda zeytin karasuların çok büyük bir çevre kirliliği oluşturduğunun belirtisidir. [45].

Zeytin karasuyunun $\mathrm{pH} 1$ 4,5-5 arasında bir değere sahiptir. Toplam katı madde içeriği \% 12 dir. Toplam uçucu katı madde içeriği ise \% 10,5' tir. Toplam $\mathrm{N}$ miktarı ise \% 2-5 arasında değişmektedir. Toplam askıda katı madde miktarı ise yaklaşık olarak \% 0,1'dir. Zeytin karasuyunun aneorobik olarak işlenmesi hem bu atığın değerlendirilmesini hem de bu atıktan enerji ve kompost gübre elde edilmesini sağlamaktadır [46].

\subsubsection{Zeytin Karasuyundan Elde Edilen Kompost Gübrenin Toprağa Faydaları}

- Toprağa humus kazandırır.

- Toprağın boşluk hacmini artırarak bitkilerin daha kolay yetiştirilmesini sağlar.

- Toprağın havalandırılmasına kolaylık kazandırır.

- Toprakta bitkilerin daha iyi yetişebilmesini sağlayan yararlı mikroorganizma sayısını artırır.

- Toprak zemininin su tutma kapasitesini artırır.

- Toprağın işlenmesini kolaylaştırır.

- Toprağa bitkiler için verilen ilave suni gübrelerin verimini artırır.

Zeytin üretimindeki atıklar yüksek miktarda KOİ, BOİ ve askıda katı değerlerine sahiptir. Bu atıklar eğer uygun bir şekilde değerlendirilmezse çok büyük bir çevre problemlerine sebep olurlar [47]. Değerlendirilemeyen zeytin atıkları ya da zeytin karasuları yer altı sularına ya da küçük göllerde su kirliliği oluştururlar. Bu kirlilikten suda yaşayan canlılar olumsuz olarak etkilenmektedir [48]. Zeytin karasuyu ve zeytin üretiminin yan ürünleri yüksek organik bileşenlere sahip olduğundan anaeorobik olarak değerlendirilebilir. Bu değerlendirilme sayesinde hem atıklar bertaraf edilir hem de enerji üretilmiş olmaktadır [49].

\subsection{Pancar Küspesi}

Pancar küspesinden biyogaz üretimi ülkemizde alternatif bir çözüm kaynağıdır. Şeker pancarının biyogaz üretimi için toplam katı miktarı \% 23' tür. 1 ton yaş şeker pancarı küspesinden yaklaşık 60-75 $\mathrm{m}^{3}$ litre biyogaz üretilebilmektedir. 2015 TÜİK verilerine göre ülkemiz yaklaşık 9 milyon ton şeker pancarı üretmiştir ve bu şeker pancarının yan ürünü olan küspeler çevre kirliliği oluşturma potansiyeline sahiptir. Aynı zamanda çok fazla biyogaz üretimi potansiyeline de sahiptir. Fakat hayvan küspesinden biyogaz üretimi genel literatürde çok az bulunmaktadır. 


\section{8. Çay Atıkları}

Ülkemizde Doğu Karadeniz bölgesinde toplanan çay miktarının yaklaşık \% 17-18' i atık olarak kalmaktadır. Ülkemiz yıllık olarak ortalama 40.000 ton çay atığı üretmektedir. Bu atıkların çevreye çürümeye terkedilmesi ve doğaya bırakılması çok büyük bir çevre kirliliğine yol açmaktadır. Çay atıkları klor azot potasyum, karbon bakımından zengindir fakat fosfor bakımından fakirdir. Çay atı̆̆ının $\mathrm{C} / \mathrm{N}$ oranı 26'dır. Biyogaz üretimi yapılırken bu de değerlendirmeler göz önünde bulundurularak yapılabilir. Çay atığının $\mathrm{pH} 1$ 5,3 tür.

Çay atıklarında protein metabolizmasını engelleyen yaklaşık $\%$ 6,3 oranında tannik asit bulunmaktadır. Bu nedenle hayvan yemi olarak kullanılması mümkün değildir. Fakat bir yöntem geliştirilmiştir ki çay atıkları gece 1/50 oranında seyreltilmiş klorsuz suyun içerisine bırakıldıktan sonra elde edilen ürünün protein içeriğinde herhangi bir değişme olmaksızın tannik asitten arıtılmış olur. Bu ürün böylece tavuk yemi olarak kullanılabilir hale getirilebilir. Bu da atığın değerlendirilmesi için alternatif bir çözüm kaynağıdır. Çay atıkları genel olarak kompost olarak, kafein üretilerek, torfla karıștırılmasıyla gübre olarak ve pellet haline dönüştürülüp yakıt olarak kullanılır. Fakat teorik olarak çay atıkları da organik bir bileşen olduğu için çeşitli düzenlemeler yapılıp biyogaz da üretilebilir. Ülkemizde şimdiye kadar çay atıklarından bir biyogaz üretimi gerçekleştirilmemiştir. Fakat çok fazla organik bileşenlere sahip olması ve miktar açısında azımsanmayacak kadar fazla olması nedeniyle ülkemizde çay atıklarından biyogaz üretimi yapılarak hem çay atıklarının değerlendirilmesine alternatif bir çözüm kaynağı hem de atıklardan enerji üretme amacıyla yapılmasına ihtiyaç vardır [50].

\subsection{Atık Su Çamuru}

Biyogaz üretimi için substrat olarak kullanılan biyokütle kaynaklarından biride kentsel atıksu arıtma çamurudur. Atıksu; tarımsal veya evsel kullanımlar sonucu kirlenmiş olan ve özellikleri kısmen değişebilen sulardır [51]. Atık suların yapısında organik madde, besin maddeleri, ağır metaller, patojen mikroorganizmalar içerdiklerinden dolayı bu suların arıtılması önem kazanmaktadır. Ülkemizde toplamda 69 tane evsel atıksu arıtma tesisi bulunmaktadır. Bu rakam ise ülkemizin nüfusunun yaklaşık \%13 üne karşıllık gelmektedir. Bu tesisler toplam olarak yıllık 500 bin tona yakın arıtma çamuru üretmektedir. Bu ise çok büyük bir biyogaz oluşum potansiyeline sahiptir [52].

Atıksu arıtma çamuru su arıtma tesislerinden elde edilen yan ürünlerdendir. Atıksu arıtma çamurundan elde edilen biyogaz içeriği ; \% 60-70 $\mathrm{CH}_{4}, \%$ 30-35 $\mathrm{CO}_{2}, \%$ 1-2 $\mathrm{H}_{2} \mathrm{~S}$ ve \% 0,3-3 $\mathrm{N}_{2}$ 'dir [53].

Atıksu arıtma çamurunun bertaraf yöntemlerinden biride biyogaz üretimidir. Atıksu arıtma çamurunun organik madde miktarı suyun cinsine göre değişiklik göstermektedir. Ülkemizdeki bu arıtma tesislerinden oluşacak gaz miktarı kişi başı $0,015-0,022 \mathrm{~m}^{3} /$ kişi - gün arasında değişiklik göstermektedir. Oluşan gazın metan yüzdesi yaklaşı \% 65 dir. Oluşan gazın 1sıl değeri ise ortalama $22,4 \mathrm{MJ} / \mathrm{m}^{3}$ ' dür [54]. Yurt dışı kaynaklı biyogaz üretimine ilişkin bilimsel makaleler incelendiğinde atık su arıtma çamurunun genellikle üretimde aşı olarak kullanıldığg görülür ve oldukça iyi bir biyogaz üretim potansiyeline sahiptir.

\subsection{Diğer Biyogaz Üretimi İçin Biyokütle Kaynakları}

Ülkemizde biyogaz üretimi için diğer kaynaklar keten, kenevir, dökülmüş ağaç yaprakları, meyve ve sebze atıkları, çimen atıkları, arpa samanı, çavdar samanı, orman ürünleri atıkları, gıda endüstrisi atıkları, organik yapılı endüstriyel atık sular, her türlü canlının yaş gübresi, her türlü atıkların organik kısımları ve bütün organik maddelerdir [55].

\section{Sonuç ve Öneriler}

Biyogaz enerjisinin diğer enerji kaynaklarından farkı ortaya çıkardığ karbondioksitin doğaya zarar vermeden bitkilerin kullandığı karbondioksite eşit olmasıdır [56]. Bu nedenle bu kaynakların yerini tutan özellikle ülkemizde büyük bir potansiyele sahip olan yenilenebilir enerji kaynaklarının üretim yöntemlerinin hızla kullanılması ve geliştirilmesi gerekmektedir. Biyogaz üretimi organik madde ve 
bazı minerallerin geri kazanılmasını sağlaması açısından avantajlıdır. Ayrıca atıkların bertaraf edilmesi, enerji kazanılması ve organik gübre elde edilmesi açısından önem kazanmaktadır.

Ülkemiz yukarıda belirtildiği gibi oldukça fazla organik atık olarak bilinen biyokütle kaynaklarına sahiptir. Bu kaynakların çoğu enerjiye dönüştürülerek yeterince değerlendirilmemekte ve bu yüzden de çevre kirliliği oluşturmaktadır. Ne yazık ki ülkemizde çok az biyogaz tesisi vardır. Bu nedenle ülkemizde biyogaz üretim tesislerinin artırılmasına, biyogaz hakkında yapılan araştırmaların geliştirilmesine ve özellikle biyogaz tesislerinin kurulumunda ihtiyaç duyulan maddi desteklere ihtiyaç duyulmaktadır.

Ülkemizde oluşturulacak olan biyogaz tesisleri, temiz enerji üretiminin yanında Türkiye' nin enerji açısından dışa bağımlılı̆̆ını azaltacak ve ekonomiye katkı sağlayacaktır.

Organik maddelerin anaerobik mikro organizmalar vasıtasıyla uygun doğa şartlarında çürümesi sonucu her yı1 590-880 milyon ton metan gazı atmosfere atılmaktadır. Atmosfere salınan metan gazının \%90'nın biyojenik kaynaklar oluşturur. Geriye kalanlar fosil yakıtlardan kaynaklanmaktadır. Kuzey yarım kürede atmosferdeki metan konsantrasyonu takriben 1,65 ppm dir. Metan gazı karbon dioksite göre 21 kat daha fazla küresel 1 sınma potansiyeline sahiptir. Metan gazının yeryüzündeki sera etkisi $\% 15$ ' dir [57].

Bu makalede biyogaz üretimi için gerekli olan organik bileşenlerin ülkemizde ne kadar fazla olduğu vurgulanmak istenmiştir. Bu organik bileşenlerin çoğu genellikle atık haldedir. Bu nedenle biyogaz üretimi hem bu atıkların değerlendirilmesi hem de enerji üretimi açısından önem kazanmaktadır. Daha önceki çalışmalarda ülkemizde biyogaz üretimi için gerekli mevcut organik atıklardan bahsedilmemiştir. Bu makalenin amacı biyogaz hakkında bilgi vermek ve biyogaz üretimi için ülkemizde var olan mevcut organik atıkların vurgulanmasını sağlamaktır.

\section{Kaynaklar}

1. Yürük F., Erdoğmuş P. 2015. Düzce İlinin Hayvansal Atıklardan Üretilebilecek Biyogaz Potansiyeli ve K-Means Kümeleme ile Optimum Tesis Konumunun Belirlenmesi, İleri Teknoloji Bilimleri Dergisi, 4(1): 47-56.

2. Toklu E., Güney M.S., Isik M., Comaklı O., Kaygusuz K. 2010. Energy Production, Consumption, Policies and Recent Developments in Turkey, Renewable and Sustainable Energy Reviews, 14: 1172-1186.

3. Türkiye Petrolleri, Ham Petrol ve Doğal Gaz Sektör Raporu. 2015. http://www.enerji.gov.tr/File/?path=ROOT\%2F1\%2FDocuments\%2FSekt\%C3\%B6r\%20Raporu \%2FTP_HAM_PETROL-DOGAL_GAZ_SEKTOR_RAPORU_2015.pdf (Erişim Tarihi: 01.03.2017).

4. Deloitte. 2014. https://www2.deloitte.com/content/dam/Deloitte/tr/Documents/energyresources/Biyok\%C3\%BCtlenin\%20alt\%C4\%B1n\%20\%C3\%A7a\%C4\%9F\%C4\%B1Sonnn.pdf (Erişim Tarihi: 02.03.2017).

5. Cordell D., Drangert J.-O., White S. 2009. The Story of Phosphorus: Global Food Security and Food for Thought, Global Environ Change, 19: 292-305.

6. Kumbur H., Özer Z., Özsoy H.D., Avcı E.D. 2015. Türkiye'de Geleneksel ve Yenilenebilir Enerji Kaynaklarının Potansiyeli ve Çevresel Etkilerinin Karşılaştırılması, III. Yenilenebilir Enerji Sempozyumu, 19-21 Ekim, Mersin, Türkiye.

7. Weiland P. 2010. Biogas Production: Current State and Perspectives, Applied Microbiology and Biotechnology, 85: 849-860.

8. Şanlıurfa Karacadağ Kalkınma Ajansı, Kompost Tesisi Kurulması Amacına Yönelik Fizibilite Çalışması Projesi Kapsamında Hazırlanan Kompost ve Biyogaz Tesisi Fizibilite Raporu. 2014. 
http://www.investsanliurfa.com/SayfaDownload/KOMPOST\%20VE\%20B\%C4\%B0YOGAZ\%2 0TES\%C4\%B0S\%C4\%B0\%20F\%C4\%B0Z\%C4\%B0B\%C4\%B0L\%C4\%B0TE\%20RAPORU.p df (Erişim Tarihi:15.03.2017).

9. Dawson C.J., Hilton J. 2010. Fertiliser Availability in A Resource-limited World: Production and Recycling of Nitrogen and Phosphorus, Food Policy, 36: 14-22.

10. Chang I.S., Zhao J., Yin X., Wu J., Jia Z., Wang L. 2011. Comprehensive Utilizations of Biogas in Inner Mongolia, Renewable and Sustainable Energy Reviews, 15: 442-1453.

11. Ahır Gübresinin Zararları, 2013. http://www.zararlari.org/ahir-gubresinin-zararlari/ (Erişim Tarihi: 03.02.2017).

12. Alçiçek A., Demirulus H. 1994. Çiftlik Gübrelerinin Biyogaz Teknolojisinde Kullanılması, Ekoloji Çevre Dergisi, 3: 5-9.

13. Biyogaz Üretimi ve Faydaları. htp.//www.alternatifpower.com.tr/resimler/2187644_1403534180.pdf (Erişim Tarihi: 01.03.2017).

14. Çanka K1lıç F. 2011. Biyogaz, Önemi, Genel Durumu ve Türkiye'deki Yeri, Mühendis ve Makina, 52 (617): 94-106.

15. Özkaya M.S., Variyenli H.İ., Yilmaz A. 2009. Güneş Enerjisi Destekli İçten Isıtmalı Fermantasyon Tankında Biyogaz Üretimi, Politeknik Dergisi, 12 (4): 255-261.

16. Ziauddin Z., Rajesh R. 2015. Production and Analysis of Biogas from Kitchen Waste, International Research Journal of Engineering And Technology, 2 (4): 622-632.

17. T.C. Millî Eğitim Bakanlığı Aile ve Tüketici Hizmetleri. Organik Atıklar. 2011. http://megep.meb.gov.tr/mte_program_modul/moduller_pdf/Organik\%20At\%C4\%B1klar.pdf (Erişim Tarihi: 03.20.2017).

18. T.C. Gida Tarım ve Hayvancılık Bakanlı̆̆1. 2017. http://www.tarim.gov.tr/ catalogs/masterpage/AnaSayfa.aspx (Erişim Tarihi: 01.04.2017).

19. Cestonaro T., Costa M.S., Costa L.A., Rozatti M.A., Pereira D.C., Lorin H.E., Carneiro L.J. 2015. The Anaerobic Co-Digestion of Sheep Bedding And $\geqslant 50 \%$ Cattle Manure Increases Biogas Production and Improves Biofertilizer Quality, Waste Management, 46: 612-618.

20. Koçer N.N., Öner C., Sugözü İ. 2006. Türkiye'de Hayvancılık Potansiyeli ve Biyogaz Üretimi, Doğu Anadolu Bölgesi Araştırmaları, 4 (2): 17-20.

21. Ilgar R. 2013. Hayvan Varlığına Göre Çanakkale Biyogaz Potansiyelinin Tespitine Yönelik Bir Çalışma, Doğu Coğrafya Dergisi, 35: 89-106.

22. Ahır Gübresinin Faydaları Nelerdir? 2015. http://www.sorhocam.com/etiket.asp?sid=1871\&ahirgubresi-faydalari-nelerdir/ (Erişim Tarihi: 06.03.2017).

23. Şahin S., Altunal N. 2008. Etlik Piliç Dışkılarının Gübre Olarak Değerlendirilmesi ve Önemi, Veteriner Tavukçuluk Derneği Dergisi, 6 (3): 6-7.

24. Türkiye İstatistik Kurumu. 2017. http://www.tuik.gov.tr/Start.do (Erişim Tarihi: 02.02.2017).

25. Tüm Atık ve Çevre Yönetimi Derneği, Atık Geri Kazanımı ve Ülkemize Etkileri. 2016. http://tayced.org/etkinlik_detay.asp?id=4 (Erişim Tarihi: 09.02.2017).

26. Lia F., Chenga S., Yua H., Yangb D. 2016. Waste From Livestock and Poultry Breeding and Its Potential Assessment of Biogas Energy in Rural China, Journal of Cleaner Production, 126: 451460.

27. Bayrakçeken H. 1997. Biyogaz Üretim Sistemi Tasarımı ve Uygulamas1, Afyon Kocatepe Üniversitesi, Fen Bilimleri Enstitüsü, Makine Eğitimi Anabilim Dalı, Yüksek Lisans Tezi, 63s, Afyon. 
28. Özkaya B., Demir A. 2010. Kompost Teknolojileri ve Uygulama Örnekleri, Organik Atıklardan Kompost ve Yenilenebilir Enerji Üretimi \& Kompost Kullanım Alanları Çalıştayı-ORAK 2010, 89 Haziran, İstanbul, Türkiye.

29. Yıldız Ş., Balahorli V., Sezer K. 2010. Organik Atıklardan Biyogaz Üretimi (Biyometanizasyon) Projesi, Su ve Çevre Dergisi, 33: 90-105.

30. T.C. Başbakanlık Türkiye İstatistik Kurumu, Belediye Atık İstatistikleri. 2008. TÜIK Haber Bülteni, Sayı:50, TÜİK, Ankara, Türkiye.

31. Sezgin N., Özcan H., Varınca K., Borat M. 2003. Kat1 Atık Depo Gazından Elektrik Üretiminin Türkiye'de Uygulanabilirliğine İki Örnek: İstanbul ve Bursa Tesisleri, Yıldız Teknik Üniversitesi Dergisi, 3: 89-96.

32. Özcan M., Öztürk S., Yıldırım M. 2011. Türkiye'nin Farklı Kaynak Tiplerine Göre Biyogaz Potansiyellerinin Belirlenmesi, IV. Enerji Verimliliği ve Kalitesi Sempozyumu, 10-12 Mayıs, Kocaeli, Türkiye.

33. Biyogaz. 2015. www.biyogaz.org.tr (Erişim Tarihi: 02.02.2017).

34. Şanlıurfa Ticaret ve Sanayi Odas1. 2010. www.sutso.org.tr (Erişim Tarihi: 02.03.2017).

35. Boztepe E, Karaca A. 2010. Yenilenebilir Enerji Kaynağı Olarak Tarımsal Atıklar, A.Ü. Ziraat Fakültesi, Toprak Bölümü, Ankara,Türkiye.

36. Dahunsia S.O., Oranusib S., Efeovbokhanc V.E. 2012. Optimization of Pretreatment, Process Performance, Mass and Energy Balance in the Anaerobic Digestion of Arachis Hypogaea (Peanut) Hull, Energy Conversion and Management, 139: 260-275.

37. Zhao Y., Yu J., Liu J., Hong Yan H., Yuan X. 2016. Material and Microbial Changes During Corn Stalk Silage and Their Effects on Methane Fermentation, Bioresource Technology, 186: 8999.

38. Boydak Tarım Serbest Tarım Danışmanlığı. 2015. http://www.boydaktarim.com/yer-fistigiyetistiriciligi/ (Erişim Tarihi: 15.03.2017).

39. Yerfistığ1 Sektör 2016. http://www.dogaka.gov.tr/Icerik/Dosya/www.dogaka.gov.tr_620_KB1O20NE_Yerfistigi-SektorRaporu-2015.pdf (Erişim Tarihi: 06.03.2017).

40. Alternatif Enerji ve Biyodizel Üreticileri Birliği. Biyogaz Üretimi. 2015. http://www.albiyobir.org.tr/biyogaz02.htm (Erişim Tarihi: 09.03.2017).

41. Zeytin Üretimi. 2014. www.marmarabirlik.com.tr (Erişim Tarihi: 19.03.2017).

42. Beccari M., Bonemazzi F., Majone M., Riccardi C. 1996. Interactions Between Acidogenesis and Methanogenesis in the Anaerobic Treatment of Olive Mill Effluent, Water Research, 30: 183-189.

43. Gelegenisa J., Georgakakisb D., Angelidakic I., Christopouloub N., Goumenakia M. 2007. Optimization of Biogas Production from Olive-oil Mill Wastewater, by Codigesting with Diluted Poultry-manure, Applied Energy, 84 (6): 646-663.

44. İkizoğlu E., Haskök S. 2005. Zeytin Karasuyunun Fiziksel Kimyasal ve İleri Yükseltgeme Yöntemleriyle Arıtımı, Kimya Mühendisliği Tmmob Kimya Mühendisleri Odası, 167: 48.

45. McNamara C.J., Anastasiou C.C., O'Flahert V., Mitchell R. 2008. Bioremediation of Olive Mill Wastewater, International Biodeterioration \& Biodegradation, 61: 27-134.

46. Orhan B., Büyük Çolak S. 2008. Zeytin Karasuyu ve Değerlendirilmesi, Ulusal Öğrenci Zeytin Kongresi, 28-30 Mayıs, Balıkesir, Türkiye.

47. Roig A., Cayuela M.L., Sanchez-Monedero M.A. 2006. An Overview on Olive Mill Wastes and Their Valorisation Methods, Waste Management, 26: 960-969. 
48. Azbar N., Bayram A., Filibeli A., Muezzinoglu A., Sengul F., Ozer A. 2004. A Review of Waste Management Options in Olive Oil Production, Critical Reviews in Environmental Science and Technology, 34: 209-247.

49. Nilgun A.O., Alev C.U, 2015. Ultrasound Pretreatment for Enhanced Biogas Production from Olive Mill Wastewater, Ultrasonics Sonochemistry, 22: 565-572.

50. Çay Atıklarının Değerlendirilmesi. 2016. http://www.mnecevre.com/cay-atiklarinindegerlendirilmesi-2 (Erişim Tarihi: 03.15.2017).

51. Atıksu Arıtma Çamuru. 2016. www.nilufer.bel.tr/kentsaglik/2_gun\%5Csalon_a\% 5Cayse_filibeli.pdf (Erişim Tarihi: 19.03.2017).

52. Kaya D. 2010. Evsel Kaynaklı Arıtma Çamurlarının Biyogaz Üretiminde Kullanımının Değerlendirilmesi, ICCI - Uluslararası Enerji ve Çevre Fuarı ve Konferansı, 12-14 Mayıs, Kocaeli, Türkiye.

53. Rulkens W. 2008. Sewage Sludge as a Biomass Resource for the Production of Energy: Overview and Assessment of the Various Options, Energy \& Fuels, 22: 9-15.

54. Büyükkamacı N., Filibeli A. 1999. Anaerobik Arıtmada Hybrid Reaktör Kullanımı, Türkiye'de Çevre Kirlenmesi Öncelikleri Sempozyumu, 18-19 Kasım, Kocaeli, Türkiye.

55. Çallı, B. 2012. Atıklardan Biyogaz Üretimi, Türkiye Kimya Derneği - Genç Kimyacılar Platformu, 4 Şubat, İstanbul, Türkiye.

56. Alçiçek A., Demirulus H., 2012. Çiftlik Gübrelerinin Biyogaz Teknolojisinde Kullanılmas1, Ekoloji Çevre Dergisi, 3: 5-9.

57. Çevre ve Orman Bakanlığı. 2006. http://www.solar-bazaar.com/menuis/Hayvan-GubresindenBiogaz-Uretimi-2005.pdf (Erişim Tarihi: 03.02.2017). 